\title{
Population structure and mitochondrial DNA gene flow in Old World populations of Drosophila subobscura
}

\author{
A. LATORRE, ${ }^{*}$ C. HERNÁNDEZ, ${ }^{*}$ D. MARTÍNEZ,* J. A. CASTRO, $\dagger$ M. RAMÓN $\dagger$ \\ \& A. MOYA* \\ * Departament de Genètica, Facultad de Biologia, Universitat de València, Spain, and †Laboratorio de Genética, \\ Departamento de Biologia, Facultad de Ciencias, Universidad de las Islas Baleares, Spain
}

\begin{abstract}
An extensive survey of mitochondrial DNA (mtDNA) restriction polymorphism in 156 isofemale lines from 29 different geographic populations of Drosophila subobscura distributed throughout the Old World was carried out. Ten restriction enzymes were used, five of which revealed restriction site polymorphism. Of the 31 restriction sites detected, 13 were found to be polymorphic. Comparisons with the mtDNA map of Drosophila yakuba indicate that the variable sites are mainly concentrated in protein genes, especially those corresponding to the NADH complex. A total of 13 different haplotypes were observed, two of which (haplotypes I and II) are quite frequent and widely distributed throughout the populations, whereas the other 11 with the exception of VIII, which deserves special attention, are each restricted to one population only and occur at low frequencies. The observed distribution of haplotypes, corroborated by a parsimonious unrooted tree, suggests an ancient origin of haplotypes I and II in the continent.

In order to compare genetic structure according to mtDNA and allozymes, the 10 populations with higher population sizes were studied for 10 polymorphic allozymes also. One striking result is the high degree of population structure of the mtDNA when compared to that obtained for allozymes. If an island model is assumed, estimates of gene flow give values of 0.013 and 1.89 migrants per generation for mtDNA and allozymes, respectively. What is apparent from these estimates is that Drosophila subobscura populations are effectively subdivided for $\mathrm{mtDNA}$ genes at migration rates at which nuclear genes (allozymes) are almost panmictic.
\end{abstract}

Keywords: allozymes, Drosophila, gene flow, mtDNA, restriction analysis.

\section{Introduction}

Drosophila subobscura is a Palaeartic species of the obscura subgroup of Drosophila, which is endemic throughout Europe (except central and northern Scandinavia) as well as the Middle East, northern Africa, and in the Atlantic islands: the Azores, Madeira and the Canaries. This species has also very recently colonized the American continent (Ayala et al., 1989 and references therein). Natural populations of $D$. subobscura have been studied extensively during the last half of this century, yielding considerable knowledge about the biogeography, ecology, behaviour, cytogenetics, population genetics and evolutionary biology of the species. Among the genetic traits studied, two are particularly relevant: allozymes (Lakovaara \&
Saura, 1971; Saura et al., 1973; Zouros et al., 1974; Marinkovic et al., 1978; Pinsker et al., 1978; Cabrera et al., 1980), which give a uniform distribution of alleles no matter which locus or geographic area is considered, and inversion polymorphisms (Krimbas \& Loukas, 1980; Prevosti et al., 1984, 1988), which exhibit clear clinal frequency distributions.

Restriction site analysis of mtDNA is being used increasingly to examine population structure or population subdivision (Avise \& Lansman, 1983; Avise et al., 1979; Takahata \& Palumbi, 1985; Ashley \& Wills, 1989; Rand \& Harrison, 1989; Crease et al., 1990; see Avise et al., 1987 \& Harrison, 1989 for relevant peculiarities of this molecule). Because of maternal and clonal inheritance, the effective population size for mitochondrial genes is only approximately one-quarter 
as large as that for nuclear genes. Thus, for equivalent mutation rates and selection pressures, the variation at equilibrium for mitochondrial genes within populations is expected to be lower, and the divergence between populations higher, than in the case of nuclear genes.

One hundred and fifty-six isofemale lines from 29 populations of $D$. subobscura distributed throughout the Old World were analysed for mtDNA restriction site polymorphism. Moreover, in order to compare the patterns of population structure for nuclear and mitochondrial genes, 10 out of the 29 populations were checked for allozyme variation also. The main purpose was to obtain information about the species history and the pattern and maintenance of population structure, especially to test the expected increased sensitivity of mtDNA to population subdivision with respect to nuclear genes.

\section{Materials and methods}

One hundred and fifty-six isofemale lines of Drosophila subobscura from different geographical regions were analysed. The number of isofemale lines per population and the populations sampled in north-to-south and east-to-west order are indicated in Table 2 . $\mathrm{mtDNA}$ data corresponding to 32 of these isofemale lines have been published elsewhere (Latorre et al., 1986).

\section{Extraction, digestion and electrophoresis of mtDNA}

An enriched fraction of mtDNA was obtained by the method described by Latorre et al. (1986). This fraction was sufficient for digestion with several restriction enzymes. We used 10 restriction enzymes. Six of them (Eco RI, HindIII, HpaI, BamHI, PstI and XbaI) recognize sequences of $6 \mathrm{bp}$; the other four (HaeIII, HpaII, $A c c \mathrm{II}$ and $C f o \mathrm{I}$ ) recognize sequences of $4 \mathrm{bp}$. In order to detect high levels of polymorphism, several of the isofemale lines were assayed additionally for five more restriction enzymes, four of them (BanII, NruI, SmaI and $X h o I)$ recognizing $6 \mathrm{bp}$ and the other one $(M n l \mathrm{I})$ recognizing $4 \mathrm{bp}$. Of these five enzymes only BanII cut the mtDNA, but always gave a monomorphic pattern. This last set of enzymes was excluded from the analysis of mtDNA differentiation.

The fragments obtained by digestion were separated on horizontal $0.6-1.2$ per cent agarose gels. To determine fragment size, lambda DNA digested with HindIII and lambda DNA double digested with HindIII-EcoRI were used as size standards. After electrophoresis, gels were stained with $0.1 \mu \mathrm{g}$ ethidium bromide $\mathrm{ml}^{-1}$ and visualized with a $260 \mathrm{~nm} \mathrm{UV} \mathrm{light}$ transilluminator.
When necessary for detecting small bands (less than $0.5 \mathrm{~kb}$ ), the gels were transferred to nylon membranes and hybridized with the single band that is obtained from HaeIII digestion of the mtDNA of some D. subobscura isofemale lines (HaeIII pattern C in Fig. 1). The slice containing this single band was cut out from a 0.6 per cent low gelling temperature agarose gel; labelling was carried out directly on the melted slices by using the digoxigenin-dUTP method. Digoxigenin labelling of the probe and detection of the hybrids were carried out according to the manufacturer's instructions (Boehringer, Mannheim).

A mtDNA restriction map was obtained by means of all possible single and double digestions of the mtDNA. The orientation of the mtDNA circle was determined by using the previously mapped fragments B and D of D. yakuba as probes (Clary \& Wolstenholme, 1985). The different restriction patterns obtained using a given enzyme and the haplotypes are named according to the notation of Latorre et al. (1986).

\section{Allozyme analysis}

A survey of 10 polymorphic allozyme loci was carried out of those populations where four or more isofemale lines were analysed for mtDNA (10 out of the 29 populations). A total of 530 flies were assayed following the techniques for gel electrophoresis and assay of enzymes as described by Ayala et al. (1972) and Brewer (1970). The 10 enzymes were: acid phosphatase $(\mathrm{ACPH})$, alcohol dehydrogenase $(\mathrm{ADH})$, catalase (CAT), fumarase (FUM), isocitrate dehydrogenase (IDH), malate dehydrogenase (MDH-1, MDH-2), octanol dehydrogenase $(\mathrm{ODH})$, superoxide dismutase (SOD), and xanthine dehydrogenase $(\mathrm{XDH})$.

\section{Statistics}

For the analysis of the degree of population structure according to allozyme and mtDNA data, $F_{\text {st }}$ (Weir \& Cockerham, 1984) and $\mathrm{N}_{\mathrm{st}}$ (Lynch \& Crease, 1990) were used respectively. The degree of mtDNA differentiation within and between populations $\left(v_{\mathrm{w}}\right.$ and $v_{\mathrm{b}}$ ) was estimated by using equations (3) and (15) of Lynch and Crease (1990).

\section{Results}

\section{$m$ IDNA analysis}

Five endonucleases yielded the same pattern in all the isofemale lines analysed (AccII, Bam HI, CfoI, PstI and $X b a \mathrm{I}$ ), while the other five were polymorphic, yielding 


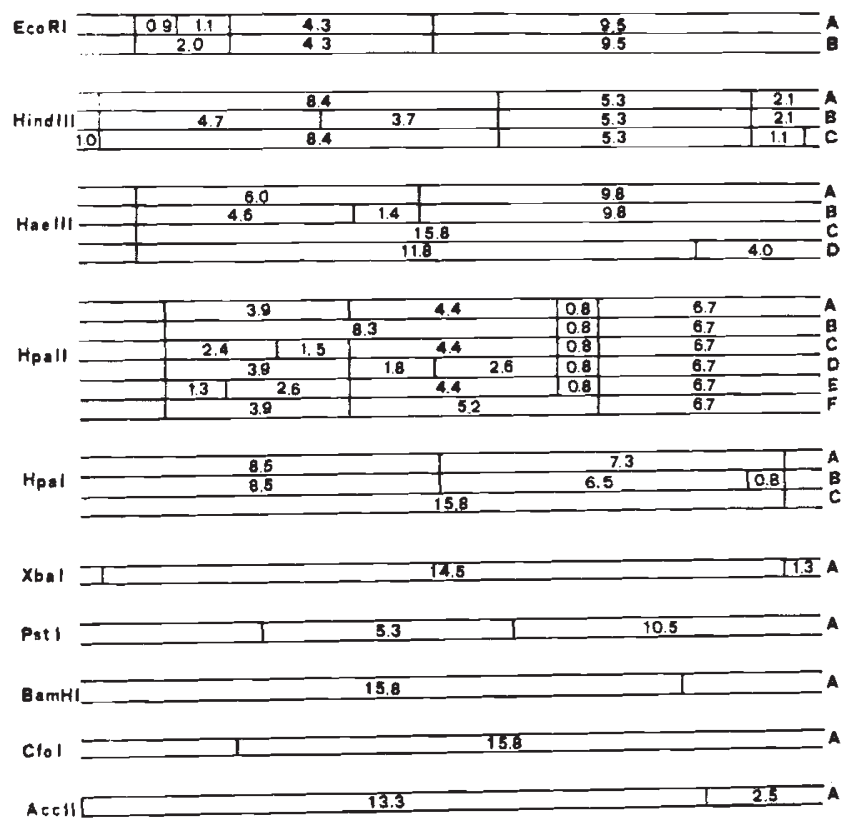

Fig. 1 Patterns obtained with the 10 restriction enzymes used in the analysis of the mtDNA of 29 populations of $D$. subobscura. Fragment sizes are indicated in kilobase pairs.

a number of restriction patterns that ranged from two $(E c o R I)$ to six (HpaII). Figure 1 shows the fragment patterns and size estimation for each of the restriction enzymes. The 10 restriction enzymes used in all isofemale lines yielded a total of 31 restrictions sites, 13 (41 per cent) of which were found to be polymorphic. Two enzymes ( $B a m \mathrm{HI}$ and $C f o I$ ) produced a single cut in the mtDNA molecule; three (PstI, XbaI and AccII) recognized two sites each. The other five enzymes (EcoRI, HindIII, HpaI, HaeIII and HpaII) recognized from 3 to 7 restriction sites as a total. Figure 2 shows an example of different patterns obtained with EcoRI and HpaII. The size of the D. subobscura mtDNA

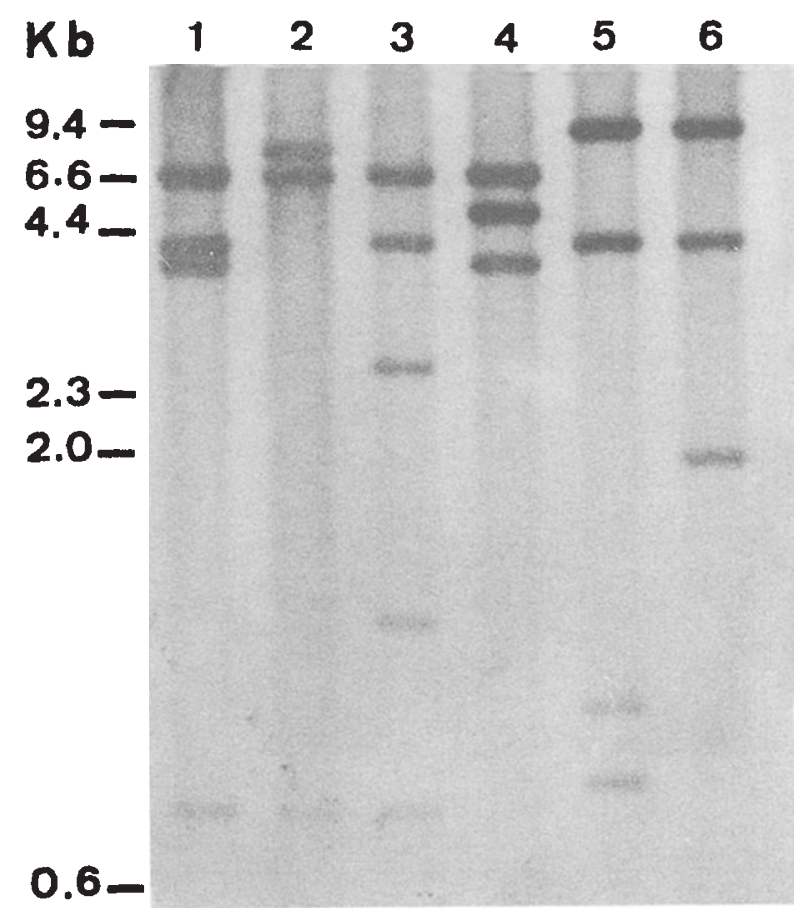

Fig. 2 Different patterns obtained when mtDNA of $D$. subobscura is digested with HpaII (lanes 1-4) and EcoRI (lanes 5 and 6$)$. Bands are detected by hybridization with a digoxigenin-dUTP labelled probe and later detection of hybrids by enzyme immunoassay. Size standards $(\mathbf{k b})$ corresponding to phage lambda DNA digested with HindIII are indicated on the left.

molecule was estimated to be $15,800 \pm 200 \mathrm{bp}$. Figure 3 shows the mtDNA cleavage map (based on the physical mtDNA map of D. yakuba; see Clary \& Wolstenholme, 1985) of the 10 restriction enzymes. As expected, polymorphic and conserved sites are not randomly distributed along the miDNA molecule.

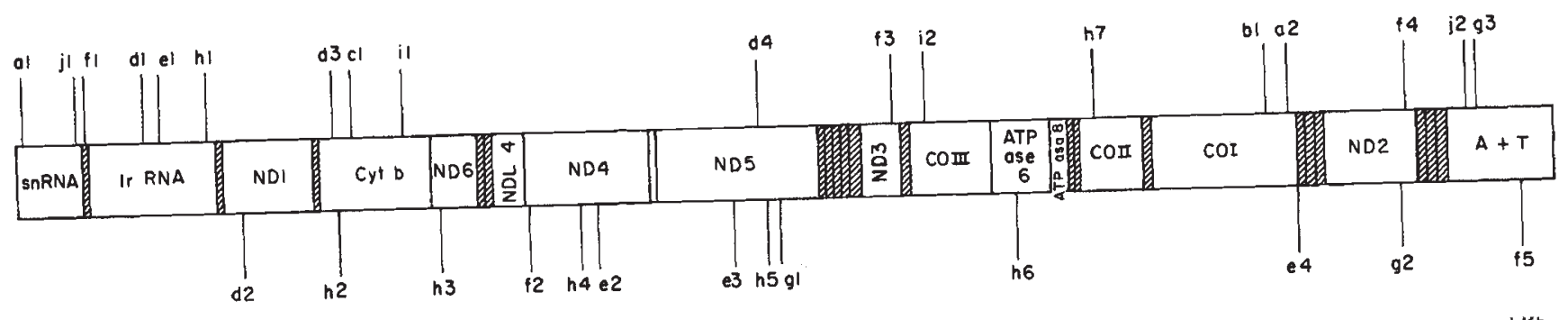

Fig. 3 D. subobscura mtDNA organization based on the genetic map of $D$. yakuba given by Clary \& Wolstenholme (1985). Conserved sites are shown above and polymorphic sites below the map. Abbreviations for the genes are as follows. srRNA and IrRNA, small and large subunits of ribosomal RNA, respectively; ND1-6, subunits of the NADH dehydrogenase complex; Cytb, cytochrome b; COI-III, subunits of cytochrome oxidase; ATP6, ATPase 6; A+ T, regulatory noncoding region. Each site is named with a letter, for each one of the restriction endonucleases, followed by a number corresponding to a specific restriction site. (a) AccII; (b) BamHI; (c) CfoI; (d) EcoRI; (e) HaeIII; (f) HindIII; (g) HpaI; (h) HpaII; (i) PstI; and (j)XbaI. 
Table 1 Polymorphic sites that define the different haplotypes. Each site is named as in the restriction map (Fig. 1). Presence or absence of a given polymorphic site is indicated by a plus $(+)$ or a minus $(-)$, respectively

\begin{tabular}{|c|c|c|c|c|c|c|c|c|c|c|c|}
\hline \multirow{2}{*}{ Haplotype } & \multirow{2}{*}{$\frac{E c o R I}{\mathrm{~d} 2}$} & \multicolumn{2}{|c|}{ HindIII } & \multicolumn{4}{|c|}{ HpaI HaeII } & \multicolumn{4}{|c|}{ HpaII } \\
\hline & & f5 & $\mathrm{f} 2$ & g1 g & $\mathrm{g} 2 \mathrm{e}$ & $3 \mathrm{e}^{2}$ & 2 e 4 & $\mathrm{~h} 4 \mathrm{~h}$ & $\mathrm{~h} 6 \mathrm{~h}$ & h3 h5 & h2 \\
\hline I & + & - & - & + & -+ & +- & - & $+t$ & + & -- & - \\
\hline II & + & - & - & + & - & -- & $=-$ & $+t$ & + & -- & - \\
\hline III & + & + & - & + & -- & -- & - & + & + & -- & - \\
\hline IV & + & - & - & + & -+ & +- & - & + & + & +- & - \\
\hline V & + & - & - & + & $+t$ & +- & - & + & + & -- & - \\
\hline VI & - & - & - & - & -+ & +- & - - & + & + & $-\quad-$ & - \\
\hline VII & + & - & + & + & -+ & ++ & - & + & + & -- & - \\
\hline VIII & + & - & + & + & -+ & ++ & - & - & + & -- & - \\
\hline IX & + & - & - & + & -- & -- & - & - & + & -- & - \\
\hline$X$ & + & - & - & + & - & - & - & + & + & -+ & - \\
\hline XI & + & - & - & + & - & - & - & + & + & -- & + \\
\hline XII & + & - & - & + & - & - & + & + & + & -- & - \\
\hline XIII & + & - & - & + & - & -- & - & + & - & -- & - \\
\hline
\end{tabular}

srRNA and IrRNA genes show no site variation while NADH complex genes seem to concentrate most of the polymorphic sites with nine out of the 13 variable sites falling into these genes. Conversely, only three out of the 18 conserved positions are located at $\mathrm{NADH}$ genes.

By combining the simple patterns obtained with the 10 enzymes we obtain a total of 13 composite patterns or haplotypes. Table 1 shows these 13 haplotypes determined by the presence or the absence of each of the 13 polymorphic sites. The haplotypes can be connected in a most parsimonious unrooted tree, which

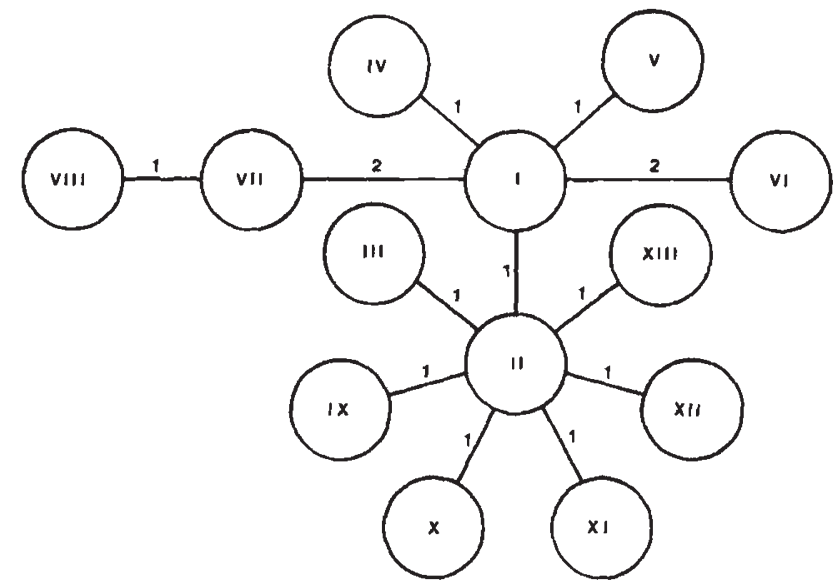

Fig. 4 Unrooted phylogenetic tree of the 13 haplotypes of D. subobscura mtDNA. The haplotypes are connected in a way that minimizes the total number of necessary site changes. The length of the branches is proportional to the number of mutational steps, as indicated on each branch. gives the minimum number of mutational steps to connect them (Fig. 4). It can clearly be seen that haplotypes I and II occupy the central position in this tree, so that they appear as intermediate molecules between any other pair of haplotypes. This suggests that haplotypes I and II are ancestral ones, which is also supported when the frequency distribution of the 13 haplotypes through the Old World is examined (Table 2). Haplotypes I and II are present in most populations sampled, and when samples are high enough (for instance, GA, $\mathrm{LI}, \mathrm{ZU}$ or CHE) they are always at high and almost identical frequencies, except in the Canary Islands, where haplotype VIII is the most frequent (see haplotype 2 distribution from Afonso et al., 1990). The rest of the haplotypes are endemic in the populations where they are detected. It is worth noticing that haplotypes I and II differ in only one HaeIII restriction site located at the ND5 locus.

The estimates of the number, $d$, of nucleotide differences per site between pairs of haplotypes were obtained by the maximum likelihood estimation method (Nei, 1987, p. 104). These values are shown at Table 3. Two sets of extreme $d$ values were obtained: low values (close to 0.004 ) were obtained among haplotypes that are separated by a single mutational step in the unrooted tree (Fig. 4). Higher values (close to 0.02 ) were obtained only when comparing haplotype VIII (endemic to the Canary Islands) to most of the endemic continental ones. The unexpected low value between haplotypes VIII and IX (endemic in Gaule; Sweden) can be explained in terms of convergence since both haplotypes share the lack of the h4 HpaIl site (Table 1). Based on $d$ values, a dendrogram was obtained (Fig. 5) by the unweighted pair-group

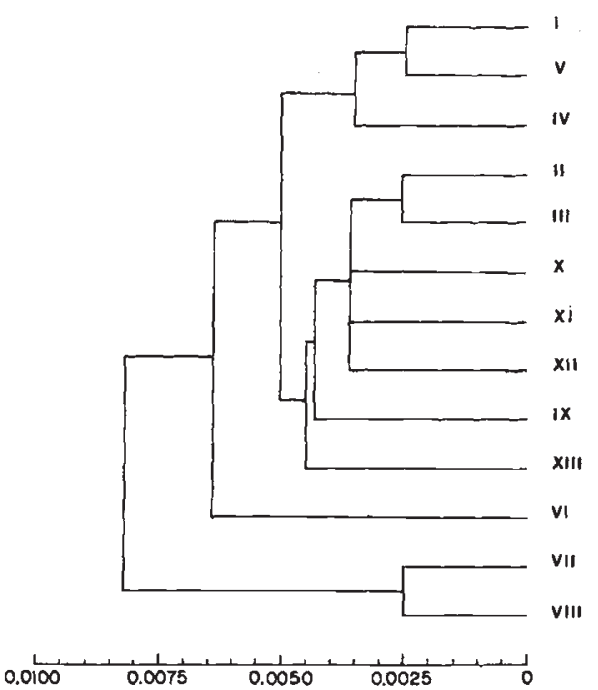

Fig. 5 Dendrogram of the 13 haplotypes obtained by the UPGMA method, based on the matrix of the number, $d$, of substitutions per nucleotide. 
Table 2 Number of isofemale lines observed for the different restriction patterns (Haplotypes) for 10 restriction enzymes in different populations of Drosophila subobscura from the Old World. The abbreviations for the populations are as follows: HE (Helsinki), GA (Gaule), LI (Lillaleden), SU (Sundsvall), SUN (Sunne), UP (Uppsala), BA (Basel), BU (Bungi), DI (Dietikon), EI (Eierbrecht), EF

(Effretikon), KA (Kaferberg), RO (Rochefort), ZU (Zurich), TU (Tubingen), LO (Lokrum), FP (Formia-Ponza), AL (Aldaya), CHE (Cheste), PM(Palma de Mallorca), RI (Ribarroja), SA (Sagunto), SAL (Saler), VI (Viver), BI (Bizerte), CH (Chechaouen), AZ (Azores), MA (Madeira) and RA (Las Raices)

\begin{tabular}{|c|c|c|c|c|c|c|c|c|c|c|c|c|c|c|}
\hline \multirow{2}{*}{$\begin{array}{l}\text { Country: } \\
\text { population }\end{array}$} & \multicolumn{14}{|c|}{ Haplotype } \\
\hline & I & II & III & IV & $\mathrm{V}$ & VI & VII & VIII & IX & $\mathrm{X}$ & XI & XII & XIII & Total \\
\hline Finland: & & & & & & & & & & & & & & \\
\hline & 4 & 2 & & & & & & & & & & & & 6 \\
\hline Sweden: & & & & & & & & & & & & & & \\
\hline GA & 12 & 10 & & & & & & & 1 & & & & & 23 \\
\hline LI & 12 & 16 & & & & & & & & & & & & 28 \\
\hline SU & 3 & & & & & & & & & & & & & 3 \\
\hline SUN & 1 & & & & & & & & & & & & & 1 \\
\hline UP & 2 & 2 & & & & & & & & & & & & 4 \\
\hline Switzerland: & & & & & & & & & & & & & & \\
\hline BA & 4 & 3 & & & & & & & & & & & & 1 \\
\hline BU & 1 & & & & & & & & & 1 & & & & $\begin{array}{l}1 \\
1\end{array}$ \\
\hline DI & & & & & & 2 & & & & & & & & $\begin{array}{l}1 \\
2\end{array}$ \\
\hline EI & & & & & & & & & & & & & & 2 \\
\hline $\begin{array}{l}\text { EF } \\
\text { KA }\end{array}$ & 2 & 1 & & & & & & & & & & & & 1 \\
\hline $\begin{array}{l}\text { KA } \\
\text { RO }\end{array}$ & 3 & & & & & & & & & & & & & 3 \\
\hline $\begin{array}{l}\text { RO } \\
\text { ZU }\end{array}$ & 10 & 10 & & & & & & & & & & 1 & 1 & 22 \\
\hline $\begin{array}{l}\text { ZU } \\
\text { Germany: }\end{array}$ & & & & & & & & & & & & & & \\
\hline $\begin{array}{l}\text { Germany: } \\
\text { TU }\end{array}$ & 2 & & & & & & & & & & & & & 2 \\
\hline Yu & & & & & & & & & & & & & & 1 \\
\hline $\begin{array}{l}\text { Italy: } \\
\text { FP }\end{array}$ & 1 & & & 1 & & & & & & & & & & 2 \\
\hline $\begin{array}{l}\text { FP } \\
\text { Spain: }\end{array}$ & & & & & & & & & & & & & & \\
\hline $\mathrm{AL}$ & 5 & 3 & & & & & & & & & & & & 8 \\
\hline $\mathrm{CHE}$ & 10 & 8 & & & & & & & & & 1 & & & 19 \\
\hline PM & & 1 & & & & & & & & & & & & 1 \\
\hline RI & 1 & 1 & & & & & & & & & & & & 2 \\
\hline SA & 4 & 1 & & & & & & & & & & & & 5 \\
\hline SAL & 1 & & & & & & & & & & & & & $\begin{array}{l}1 \\
4\end{array}$ \\
\hline VI & 2 & 2 & & & & & & & & & & & & 4 \\
\hline $\begin{array}{l}\text { Tunisia: } \\
\text { BI }\end{array}$ & & & & & 1 & & & & & & & & & 1 \\
\hline $\begin{array}{l}\text { Morocco: } \\
\text { CH }\end{array}$ & & & 1 & & & & & & & & & & & 1 \\
\hline $\begin{array}{l}\mathrm{CH} \\
\text { Azores } \mathrm{AZ}\end{array}$ & & 2 & 1 & & & & & & & & & & & 2 \\
\hline $\begin{array}{l}\text { Azores AZ } \\
\text { Madeira MA }\end{array}$ & & 1 & & & & & & & & & & & & 1 \\
\hline Canary Is. RA & & & & & & & 1 & 1 & & & & & & 2 \\
\hline Total & 76 & 68 & 1 & 1 & 1 & 2 & 1 & 1 & 1 & 1 & 1 & 1 & 1 & 156 \\
\hline
\end{tabular}

method, UPGMA, of cluster analysis. The dendrogram shows two major clusters: one formed by haplotypes I, V and IV; and the other by haplotypes II, III and IX-XIII. Haplotypes VI, VII and VIII are the most separated. In general, there is good agreement between the unrooted and most parsimonius tree shown in Fig. 4 and the UPGMA cluster. However, the tree gives additional information: haplotypes VI, VII and VIII 
Table 3 Genetic differentiation between the 13 mtDNA haplotypes of $D$. subobscura estimated as $d$, the number of nucleotide substitutions per site. Values are multiplied by $10^{4}$

\begin{tabular}{|c|c|c|c|c|c|c|c|c|c|c|c|c|c|}
\hline Haplotype & I & II & III & IV & V & VI & VII & VIII & IX & $\mathrm{X}$ & XI & XII & XII \\
\hline I & - & 42 & 82 & 40 & 40 & 87 & 79 & 123 & 86 & 83 & 83 & 83 & 86 \\
\hline II & & - & 41 & 83 & 82 & 134 & 123 & 169 & 43 & 42 & 42 & 42 & 43 \\
\hline III & & & - & 122 & 121 & 176 & 161 & 208 & 85 & 82 & 82 & 82 & 85 \\
\hline IV & & & & - & 79 & 130 & 119 & 163 & 128 & 124 & 124 & 124 & 128 \\
\hline V & & & & & - & 128 & 117 & 161 & 127 & 123 & 123 & 123 & 127 \\
\hline VI & & & & & & - & 170 & 220 & 185 & 179 & 179 & 179 & 185 \\
\hline VII & & & & & & & - & 38 & 169 & 163 & 163 & 163 & 169 \\
\hline VIII & & & & & & & & - & 127 & 210 & 210 & 210 & 218 \\
\hline IX & & & & & & & & & - & 86 & 86 & 86 & 89 \\
\hline $\mathrm{X}$ & & & & & & & & & & - & 83 & 83 & 86 \\
\hline XI & & & & & & & & & & & - & 83 & 86 \\
\hline XII & & & & & & & & & & & & - & 86 \\
\hline XIII & & & & & & & & & & & & & \\
\hline
\end{tabular}

appear closer to haplotype I than to haplotype II, which gives an idea of historical relationships among these haplotypes.

Taking into account the $d$ values shown in Table 3 , as well as the mean distribution of the 13 haplotypes through the Old World (Table 2), the total nucleotide diversity, $H_{\mathrm{T}}$, for mtDNA of $D$. subobscura was estimated to be 0.0043 . This is in good agreement with values reported previously for other Drosophila species (Nei, 1987).

\section{Allozyme variation}

Table 4 shows the estimated allele frequencies as well as expected heterozygosity, $H$, per locus and per population of the 10 loci examined in the present study. Our estimate of $H=0.085$ is quite close to others reported previously (Cabrera et al., 1980 and references therein). All the separate loci are polymorphic; five of them (Fum, Idh, Mdh-2, Odh, and Xdh) show single allelic variants found in one single locality. Heterozygosity per locus ranges from 0.013 in $M d h-2$ to 0.303 in $A c p h$. The heterozygosity values per population are somewhat more uniform, ranging from 0.044 for HE (Finland) to 0.143 for ZU (Switzerland).

\section{mtDNA and allozyme population subdivision}

mtDNA differentiation within and between populations was estimated only for the 10 populations where the sample size was four or more. Values are shown at Table 5. The mean mtDNA differentiation within populations was found by averaging $v_{\mathrm{w}}$ to be 0.0001 . The nucleotide divergence between populations ranges from 0.0016 between SA (Spain) and HE (Finland) to 0.0027 between CHE (Spain) and ZU (Switzerland). Some other high divergence values close to 0.0025 also arise in comparisons with the $\mathrm{ZU}$ population. We do not include in Table 5 data from the two samples from RA (Canary Islands), and the exclusion of this population explains why the range of variation is narrow in comparison with the one obtained by Afonso et al. (1990) in which the Canary populations are much more differentiated from the rest (with a mean $v_{\mathrm{b}}$ value of 0.019$)$. In spite of that, there was enough variation among the 10 populations analysed to suggest that there is a population substructure. In fact, the $N_{\mathrm{st}}$ value was 0.974 , substantially higher than the value obtained for the equivalent statistic for allozyme differentiation $\left(F_{\text {st }}\right)$, which was estimated to be 0.117 . One conclusion emerges from these data: $D$. subobscura populations are more substructured according to mtDNA than to nuclear markers. This is not the first study to reach this conclusion (DeSalle et al., 1987), but it has been demonstrated by undertaking both mtDNA and allozyme analysis within the same populations.

If it is assumed that populations are at equilibrium under an island model, it is indirectly possible to estimate gene flow as $N m$, where $N$ is the average population size of a population divided into distinct demes and $m$ is the average fraction of a deme that is replaced by immigrants in any generation. For allozymes, $N m$ was estimated according to Slatkin (1989). For mtDNA, $\mathrm{Nm}$ was derived from Takahata \& Palumbi's (1985) equation for $G_{\text {st }}$ at equilibrium but working with $N_{\text {st }}$ instead of $G_{\text {st }}$. The $N m$ estimate of gene flow for allozymes was 1.89 , whereas for mtDNA $\mathrm{Nm}$ fell to a value of 0.013 . If we consider the gene 
Table 4 Frequency of alternate alleles and expected mean heterozygosity per locus and per population in 10 Old World populations of $D$. subobscura. Except for the $A d h$ locus, the alleles are ordered from low to high electrophoretic mobility. Number of flies analysed for each population is indicated within parentheses

Geographical population

\begin{tabular}{|c|c|c|c|c|c|c|c|c|c|c|c|c|c|}
\hline Locus & Allele & $\begin{array}{l}\text { HE } \\
(50)\end{array}$ & $\begin{array}{l}\text { GA } \\
(75)\end{array}$ & $\begin{array}{l}\mathrm{LI} \\
(140)\end{array}$ & $\begin{array}{l}\text { UP } \\
(20)\end{array}$ & $\begin{array}{l}\mathrm{BA} \\
(30)\end{array}$ & $\begin{array}{l}\text { ZU } \\
(100)\end{array}$ & $\begin{array}{l}\mathrm{AL} \\
(35)\end{array}$ & $\begin{array}{l}\text { CHE } \\
(75)\end{array}$ & $\begin{array}{l}\text { SA } \\
(10)\end{array}$ & $\begin{array}{l}\text { VI } \\
(20)\end{array}$ & Mean & Heterozygosity \\
\hline Acph & $\begin{array}{l}1 \\
2 \\
3 \\
4 \\
5\end{array}$ & $\begin{array}{l}0.000 \\
0.000 \\
0.980 \\
0.000 \\
0.020\end{array}$ & $\begin{array}{l}0.040 \\
0.000 \\
0.860 \\
0.027 \\
0.073\end{array}$ & $\begin{array}{l}0.046 \\
0.000 \\
0.832 \\
0.029 \\
0.093\end{array}$ & $\begin{array}{l}0.000 \\
0.000 \\
0.900 \\
0.000 \\
0.100\end{array}$ & $\begin{array}{l}0.000 \\
0.000 \\
0.967 \\
0.000 \\
0.033\end{array}$ & $\begin{array}{l}0.329 \\
0.000 \\
0.750 \\
0.000 \\
0.095\end{array}$ & $\begin{array}{l}0.020 \\
0.114 \\
0.429 \\
0.000 \\
0.129\end{array}$ & $\begin{array}{l}0.000 \\
0.000 \\
0.947 \\
0.000 \\
0.033\end{array}$ & $\begin{array}{l}0.000 \\
0.300 \\
0.550 \\
0.150 \\
0.000\end{array}$ & $\begin{array}{l}0.155 \\
0.000 \\
0.725 \\
0.200 \\
0.075\end{array}$ & $\begin{array}{l}0.059 \\
0.794 \\
0.041 \\
0.065 \\
0.041\end{array}$ & 0.303 \\
\hline$A d h$ & $\begin{array}{l}S \\
S^{\prime} \\
S^{\prime \prime} \\
S^{*}\end{array}$ & $\begin{array}{l}1.000 \\
0.000 \\
0.000 \\
0.000\end{array}$ & $\begin{array}{l}1.000 \\
0.000 \\
0.000 \\
0.000\end{array}$ & $\begin{array}{l}0.993 \\
0.007 \\
0.000 \\
0.000\end{array}$ & $\begin{array}{l}1.000 \\
0.000 \\
0.000 \\
0.000\end{array}$ & $\begin{array}{l}1.000 \\
0.000 \\
0.000 \\
0.000\end{array}$ & $\begin{array}{l}0.960 \\
0.010 \\
0.020 \\
0.010\end{array}$ & $\begin{array}{l}1.000 \\
0.000 \\
0.000 \\
0.000\end{array}$ & $\begin{array}{l}0.967 \\
0.000 \\
0.033 \\
0.000\end{array}$ & $\begin{array}{l}1.000 \\
0.000 \\
0.000 \\
0.000\end{array}$ & $\begin{array}{l}1.000 \\
0.000 \\
0.000 \\
0.000\end{array}$ & $\begin{array}{l}0.992 \\
0.002 \\
0.005 \\
0.000\end{array}$ & 0.016 \\
\hline Cat & $\begin{array}{l}1 \\
2\end{array}$ & $\begin{array}{l}0.960 \\
0.040\end{array}$ & $\begin{array}{l}0.887 \\
0.113\end{array}$ & $\begin{array}{l}0.871 \\
0.129\end{array}$ & $\begin{array}{l}0.875 \\
0.125\end{array}$ & $\begin{array}{l}0.917 \\
0.183\end{array}$ & $\begin{array}{l}0.885 \\
0.115\end{array}$ & $\begin{array}{l}0.929 \\
0.071\end{array}$ & $\begin{array}{l}0.920 \\
0.080\end{array}$ & $\begin{array}{l}0.800 \\
0.200\end{array}$ & $\begin{array}{l}0.925 \\
0.075\end{array}$ & $\begin{array}{l}0.897 \\
0.103\end{array}$ & 0.182 \\
\hline Fum & $\begin{array}{l}1 \\
2 \\
3 \\
4\end{array}$ & $\begin{array}{l}0.000 \\
1.000 \\
0.000 \\
0.000\end{array}$ & $\begin{array}{l}0.000 \\
1.000 \\
0.000 \\
0.000\end{array}$ & $\begin{array}{l}0.000 \\
0.989 \\
0.011 \\
0.000\end{array}$ & $\begin{array}{l}0.000 \\
0.975 \\
0.000 \\
0.025\end{array}$ & $\begin{array}{l}0.000 \\
0.933 \\
0.000 \\
0.067\end{array}$ & $\begin{array}{l}0.005 \\
0.715 \\
0.280 \\
0.000\end{array}$ & $\begin{array}{l}0.000 \\
1.000 \\
0.000 \\
0.000\end{array}$ & $\begin{array}{l}0.000 \\
1.000 \\
0.000 \\
0.000\end{array}$ & $\begin{array}{l}0.000 \\
0.800 \\
0.000 \\
0.200\end{array}$ & $\begin{array}{l}0.000 \\
1.000 \\
0.000 \\
0.000\end{array}$ & $\begin{array}{l}0.001 \\
0.941 \\
0.029 \\
0.029\end{array}$ & 0.0 \\
\hline$I d h$ & $\begin{array}{l}1 \\
2 \\
3 \\
4\end{array}$ & $\begin{array}{l}0.000 \\
0.060 \\
0.940 \\
0.000\end{array}$ & $\begin{array}{l}0.000 \\
0.000 \\
1.000 \\
0.000\end{array}$ & $\begin{array}{l}0.000 \\
0.007 \\
0.993 \\
0.004\end{array}$ & $\begin{array}{l}0.000 \\
0.075 \\
0.925 \\
0.000\end{array}$ & $\begin{array}{l}0.000 \\
0.000 \\
1.000 \\
0.000\end{array}$ & $\begin{array}{l}0.000 \\
0.015 \\
0.985 \\
0.000\end{array}$ & $\begin{array}{l}0.000 \\
1.000 \\
1.000 \\
0.000\end{array}$ & $\begin{array}{l}0.007 \\
1.000 \\
0.973 \\
0.000\end{array}$ & $\begin{array}{l}0.000 \\
0.800 \\
1.000 \\
0.000\end{array}$ & $\begin{array}{l}0.000 \\
1.000 \\
1.000 \\
0.000\end{array}$ & $\begin{array}{l}0.001 \\
0.017 \\
0.982 \\
0.000\end{array}$ & .035 \\
\hline$M d h-1$ & $\begin{array}{l}1 \\
2 \\
3\end{array}$ & $\begin{array}{l}0.880 \\
0.120 \\
0.000\end{array}$ & $\begin{array}{l}0.967 \\
0.027 \\
0.007\end{array}$ & $\begin{array}{l}0.914 \\
0.086 \\
0.000\end{array}$ & $\begin{array}{l}0.850 \\
0.150 \\
0.000\end{array}$ & $\begin{array}{l}0.900 \\
0.083 \\
0.017\end{array}$ & $\begin{array}{l}0.955 \\
0.045 \\
0.000\end{array}$ & $\begin{array}{l}0.957 \\
0.043 \\
0.000\end{array}$ & $\begin{array}{l}0.993 \\
0.007 \\
0.000\end{array}$ & $\begin{array}{l}0.950 \\
0.050 \\
0.000\end{array}$ & $\begin{array}{l}1.000 \\
0.000 \\
0.000\end{array}$ & $\begin{array}{l}0.937 \\
0.061 \\
0.002\end{array}$ & 0.115 \\
\hline$M d h-2$ & $\begin{array}{l}1 \\
2 \\
3\end{array}$ & $\begin{array}{l}0.000 \\
1.000 \\
0.000\end{array}$ & $\begin{array}{l}0.000 \\
1.000 \\
0.000\end{array}$ & $\begin{array}{l}0.000 \\
0.986 \\
0.014\end{array}$ & $\begin{array}{l}0.000 \\
1.000 \\
0.000\end{array}$ & $\begin{array}{l}0.000 \\
1.000 \\
0.000\end{array}$ & $\begin{array}{l}0.050 \\
0.950 \\
0.000\end{array}$ & $\begin{array}{l}0.000 \\
1.000 \\
0.000\end{array}$ & $\begin{array}{l}0.000 \\
1.000 \\
0.000\end{array}$ & $\begin{array}{l}0.000 \\
1.000 \\
0.000\end{array}$ & $\begin{array}{l}0.000 \\
1.000 \\
0.000\end{array}$ & $\begin{array}{l}0.000 \\
0.994 \\
0.001\end{array}$ & 0.013 \\
\hline Odh & $\begin{array}{l}1 \\
2 \\
3\end{array}$ & $\begin{array}{l}0.000 \\
1.000 \\
0.000\end{array}$ & $\begin{array}{l}0.000 \\
1.000 \\
0.000\end{array}$ & $\begin{array}{l}0.004 \\
0.986 \\
0.010\end{array}$ & $\begin{array}{l}0.000 \\
1.000 \\
0.000\end{array}$ & $\begin{array}{l}0.000 \\
1.000 \\
0.000\end{array}$ & $\begin{array}{l}0.000 \\
0.980 \\
0.020\end{array}$ & $\begin{array}{l}0.000 \\
1.000 \\
0.000\end{array}$ & $\begin{array}{l}0.000 \\
0.867 \\
0.133\end{array}$ & $\begin{array}{l}0.000 \\
1.000 \\
0.000\end{array}$ & $\begin{array}{l}0.000 \\
0.975 \\
0.025\end{array}$ & $\begin{array}{l}0.000 \\
0.981 \\
0.019\end{array}$ & 0.035 \\
\hline Sod & $\begin{array}{l}1 \\
2\end{array}$ & $\begin{array}{l}0.000 \\
1.000\end{array}$ & $\begin{array}{l}0.000 \\
1.000\end{array}$ & $\begin{array}{l}0.025 \\
0.975\end{array}$ & $\begin{array}{l}0.025 \\
0.975\end{array}$ & $\begin{array}{l}0.050 \\
0.950\end{array}$ & $\begin{array}{l}0.010 \\
0.990\end{array}$ & $\begin{array}{l}0.045 \\
0.955\end{array}$ & $\begin{array}{l}0.000 \\
1.000\end{array}$ & $\begin{array}{l}0.000 \\
1.000\end{array}$ & $\begin{array}{l}0.000 \\
1.000\end{array}$ & $\begin{array}{l}0.015 \\
0.985\end{array}$ & 0.030 \\
\hline$X d h$ & $\begin{array}{l}1 \\
2 \\
3 \\
4\end{array}$ & $\begin{array}{l}0.000 \\
0.000 \\
1.000 \\
0.000\end{array}$ & $\begin{array}{l}0.000 \\
0.007 \\
0.987 \\
0.006\end{array}$ & $\begin{array}{l}0.000 \\
0.011 \\
0.989 \\
0.000\end{array}$ & $\begin{array}{l}0.000 \\
0.000 \\
1.000 \\
0.000\end{array}$ & $\begin{array}{l}0.000 \\
0.017 \\
0.950 \\
0.033\end{array}$ & $\begin{array}{l}0.005 \\
0.025 \\
0.970 \\
0.000\end{array}$ & $\begin{array}{l}0.000 \\
0.000 \\
0.971 \\
0.029\end{array}$ & $\begin{array}{l}0.000 \\
0.000 \\
1.000 \\
0.000\end{array}$ & $\begin{array}{l}0.000 \\
0.000 \\
1.000 \\
0.000\end{array}$ & $\begin{array}{l}0.000 \\
0.000 \\
1.000 \\
0.000\end{array}$ & $\begin{array}{l}0.001 \\
0.006 \\
0.987 \\
0.004\end{array}$ & 0.026 \\
\hline & & 044 & 0.054 & 0.085 & 0.090 & 0.072 & 0.143 & 0.103 & 0.061 & 0.132 & 0.062 & & 0.085 \\
\hline
\end{tabular}

flow ratio between allozymes and mtDNA, it is apparent that gene flow is much higher for allozymes than for mtDNA.

\section{Discussion}

Our current estimation of the size of the mtDNA molecule of $D$. subobscura has taken into account the posi- tion on the D. yakuba sequence (Clary \& Wolstenholme, 1985) of three HindIII sites that are well conserved among species (Solignac et al., 1986), as well as an exhaustive analysis of the $\mathrm{A}+\mathrm{T}$ region that is currently being done in our laboratory, which gives an estimated size for the small $D$. subobscura HindIII fragment of $2.1 \mathrm{~kb}$.

Although the distribution of the sites along the 
Table $5 \mathrm{mtDNA}$ differentiation within and between 10 populations of $D$. subobscura. Values on the main diagonal are within population differentiation, $v_{\mathrm{w}}$. Values above diagonal are between population differentiation, $v_{\mathrm{b}}$. Values are multiplied by $10^{6}$

\begin{tabular}{lrrrrrrrrrr}
\hline HE & 62 & 2206 & 2146 & 1962 & 1925 & 2496 & 1858 & 2226 & 1599 & 1962 \\
GA & & 5 & 2278 & 2180 & 2230 & 2659 & 2227 & 2477 & 2180 & 2180 \\
LI & & & 3 & 1991 & 2096 & 2434 & 2135 & 2308 & 2223 & 1991 \\
UP & & & & 173 & 1968 & 2376 & 1975 & 2207 & 1959 & 1906 \\
BA & & & & & 48 & 2466 & 1963 & 2254 & 1843 & 1968 \\
ZU & & & & & & 6 & 2493 & 2688 & 2544 & 2376 \\
AL & & & & & & 35 & 2249 & 1717 & 1975 \\
CHE & & & & & & & 7 & 2194 & 2207 \\
SA & & & & & & & & 67 & 1959 \\
VI & & & & & & & & & 173 \\
\hline
\end{tabular}

mtDNA genes (Fig. 3) is basically the same as that obtained by Afonso et al. (1990), we disagree with their precise location of some restriction sites, mainly those that are well conserved among different Drosophila species: our named $\mathrm{j} 1, \mathrm{f} 1, \mathrm{~d} 1$, e 1 and $\mathrm{h} 1$ sites (Fig. 3), seem to be more in accordance with their distribution among species (Solignac et al., 1986). There is also one variable site that has been wrongly placed by Afonso et al. Although it is difficult comparing among variable sites, this one (our named $\mathrm{e} 2$ ) is the one that defines pattern B of HaelII (Fig. 1), which is the most common in the Canary Islands, being present in both our two RA (Canary Islands) isofemale lines.

If we take our data and Afonso et al.'s (1990) data, the distribution pattern of mtDNA haplotypes is together dominated by three haplotypes: I and II mostly present in all populations at high frequencies (except in the Canary Islands, where they exist but at low frequencies and haplotype VIII which is the most widely distributed in the Canary Islands and is absent from the other populations. The remaining haplotypes arise as locally appearing variants that are either selected against or else randomly eliminated by, for instance, cold winter bottlenecks. With our data, however, when samples are large enough (see for example GA and LI from northern, $\mathrm{ZU}$ from central and $\mathrm{CHE}$ from southern Europe), frequencies of haplotypes I and II do not seem to be changing according to geographical origin and do not show the kind of north to south clinal distribution that is described by Afonso et al. for the Hae III patterns that define these two haplotypes. In fact, the quasi-identical distribution of haplotypes I and II in the continent is consistent with selective values being similar. The number of nucleotide substitutions per site between haplotypes I and II is 0.0042 (Table 3, see also haplotypes 3 and 13 of Fig. 4 by Afonso et al., $1990)$. It is likely that most of the differences in nucleotide bases are at synonymous codon positions and, consequently, that these two haplotypes produce mostly similar protein products.

The mean number of nucleotide substitutions per site between haplotype VIII and haplotypes I and II is 0.0146 . The fact that neither haplotype VIII nor any of its closer derivatives (those with the HindIII B and HaelII B patterns in Fig. 1) are found in the continent, and that haplotypes I and II have not succeeded in the Canary Islands, suggests the possibility of selection, although very reduced flow between the islands and the continent cannot be ruled out. Selection could be acting on some coadaptation between the nuclear background and the mitochondrial genes (Fos et al., 1990). Consequently, mtDNA polymorphisms observed in natural populations could be affected by interactions among nuclear polymorphisms, random genetic drift, founder events and direct selection on the mtDNA haplotypes. Although we agree with Afonso et al. in that the polymorphism found in the Canary Islands is an ancient polymorphism that has reached a more evolved stage than on the continent, our estimates of mtDNA differentiation, within and between populations (Table 5), suggest that continental populations have had enough time to reach a microgeographical structure. To our understanding this forbids grouping of samples following the simple criterion of being collected in the same country. We have, preferred therefore, to include in the population analysis only those populations where a sample of four or more was collected instead of grouping samples from different localities. Table 5 shows that mtDNA differentiation among populations is at least one order of magnitude higher than the within population values, but no correlation between divergence and geographical distance can be detected. This supports the idea of a microgeographical heterogeneity for mtDNA provoked by a low gene flow. Extreme low levels of gene flow would result in higher divergence between populations. This is the 
case when comparing RA populations from the Canary Islands with any other population, for which our data (not included at Table 5) give a mean $d$ value of 0.013 (quite close to the 0.0119 value obtained by Afonso et al., 1990).

Our main result has been to demonstrate how the observed levels and distribution of mtDNA polymorphism in $D$. subobscura in the Old World support the idea that mtDNA variation is highly structured $\left(N_{\mathrm{st}}=0.974\right)$, with a low rate of gene flow probably being the main factor contributing to the observed population structure (Birky et al., 1983; Takahata \& Palumbi, 1985; DeSalle et al., 1987; Hale \& Singh, 1987; Crease et al., 1990). On the other hand, the distribution of allozyme variation is less structured $\left(F_{\text {st }}=0.117\right)$. The estimates of gene flow are quite close to two adults per generation, and probably higher, in general agreement with results reported previously (Lakovaara \& Saura, 1973; Cabrera et al., 1980) which show that enzyme polymorphism in $D$. subobscura is rather uniform throughout the distributional range of the species. As for allozymes, the distribution of mtDNA haplotypes is far from the latitudinal clinal distribution observed in the case of chromosomal polymorphisms (Krimbas \& Loukas, 1980; Prevosti et al., 1988; Ayala et al., 1989).

Evidence of a low rate of mtDNA gene flow is also documented in other Drosophila species. This, for instance, is the case in D. melanogaster (Hale \& Singh, 1987; Singh \& Rhomberg, 1987). Although DeSalle et al. (1987) do not find any significant difference between male and female dispersion in populations of $D$. mercatorum, they claim that it is not difficult to get $\mathrm{Nm}$ estimates six to eight times higher for mtDNA than for nuclear (alloyzme) genes when the dispersal behaviour of males and females is different. We do not have to specifically test this statement with $D$. subobscura. Baba-Aissa et al. (1988) and Nigro (1988) have found a great uniformity of mtDNA haplotypes of $D$. simulans. They suggest that recent founder effects could be responsible for such uniformity. In other words, $D$. simulans is not yet structured because no local endemic haplotypes have yet appeared, or if they have appeared they have been quickly extinguished. In the case of D. subobscura our $N m$ estimate for mtDNA is much smaller than for allozymes, supporting the idea that mitochondrial genes diverge more extensively in subdivided populations than nuclear genes do (DeSalle et al., 1987; Crease et al., 1990). Our figures are not precise, but it is apparent that when patterns of mtDNA and allozyme subdivision are jointly considered, the $D$. subobscura populations are bordering the line that separates panmixia from subdivision. The gene flow is high enough to cause near panmixia for neutral or quasi-neutral nuclear markers while it is low enough to mtDNA to allow effective genetic differentiation.

\section{Acknowledgements}

We are indebted to Dr Wolstenholme for providing us with mtDNA clones of D. yakuba; Drs Jungen, Saura and Serra for sending us $D$. subobscura strains and $\mathrm{Dr}$ F. J. Ayala for revising the manuscript. This work has been supported by grant PB86-0517 of 'Direccion General de Investigacion Cientifica y Tecnica' (Spain) to AM, and also by three fellowships, two for 'Perfeccionamiento del Profesorado' and one for 'Formacion del Personal Investigador, Ministerio de Educacion y Ciencia' (Spain) to AM, AL and DM, respectively.

\section{References}

AFONSO, J. M., VOLZ, A., HERNANDEZ, M., RUTTKAY, H., GONZALEZ, A. M., LARRUGA, J. M., CABRERA, V. AND SPERLICH, D. 1990. Mitochondrial DNA variation and genetic structure in Old-World populations of Drosophila subobscura. Mol. Biol. Evol., 7, 123-142.

ASHLEY, M. V. AND WILL, C. 1989. Mitochondrial and allozyme divergence patterns are correlated among island deer mice. Evolution, 43, 646-650.

AVISE, J. C., ARNOLD, J., BALL, R. M., BERMINGHAM, E., LAMB, T., NEIGEL, J. E., REEB, C. A. AND SAUNDERS, N. 1987. Intraspecific phylogeography: the mitochondrial DNA bridge between population genetics and systematics. Ann. Rev. Ecol. Syst., 18, 489-522.

AVISE, J. C. AND LANSMAN, R. C. 1983. Polymorphism of mitochondrial DNA in populations of higher animals. In: Nei, M. and Koehn, R. K. (eds) Evolution of Genes and Proteins, Sinauer, Sunderland, Massachusetts, pp. 147-164.

AVISE, J. C., LANSMAN, R. A. AND SHADE, R. D. 1979. The use of restriction endonucleases to measure mitochondrial DNA sequence relatedness in natural populations. I. Population structure and evolution in the genus Peromyscus. Genetics, 92, 279-295.

AYALA, F. J., POWELL, J. R., TRACEY, M. L., MOURAO, C. A. AND PEREZSALAS, S. 1972. Enzyme variability in the Drosophila willistoni group. III. Genic variation in natural populations of Drosophila willistoni. Genetics, 70, 113-139.

AYALA, F. J., SERRA, L. AND PREVOSTI, A. 1989. A grand experiment in evolution: the Drosophila subobscura colonization of the Americas. Drosophila suboscura. Genome, 31, 246-255.

BABA-AISSA, F., SOLIGNAC, M., DENNEBOUY, N. AND DAVID, J. R. 1988. Mitochondrial DNA variability in Drosophila simulans: quasi-absence of polymorphism within each of the three cytoplasmic races. Heredity, 61, 419-426.

BIRKY, C. W., FUERST, P. AND MARUYAMA, T. 1989. Organelle gene diversity under migration, mutation, and drift: equilibrium expectations, approach to equilibrium, effects of heteroplasmic cells, and comparison to nuclear genes. Genetics, 121, 613-627. 
BIRKY, C. W., MARUYAMA, T. AND FUERST, P. 1983. An approach to population and evolutionary genetic theory for genes in mitochondria and chloroplasts, and some results. Genetics, 103, 513-527.

BREWER, G. J. 1970. An Introduction to Isozymes Techniques. Academic Press, New York.

CABreRA, v. M., GonZALEZ, A. M. AND GULlon, A. 1980. Enzymatic polymorphism in Drosophila subobscura populations from the Canary Islands. Evolution, 34, 875-887.

CLARY, D. O. AND WOLSTENHOLME, D. R. 1985. The mitochondrial DNA molecular of Drosophila yakuba: nucleotide sequence, gene organization, and genetic code. J. Mol. Evol., 22, 252-271.

CREASE, T. J., LYNCH, M. AND SPITZE, K. 1990. Hierarchical analysis of population genetic variation in mitochondrial and nuclear genes of Daphnia pulex. Mol. Biol. Evol., 7, 444-458.

DESALLE, R. AND HUNT, J. H. 1987. Molecular evolution in Hawaiian drosophilids. Trends in Ecology and Evolution, 2, 212-216.

DESALLE, R., TEMPLETON, A., MORI, I., PLETSCHER, S. AND JOHNSTON, J. S. 1987. Temporal and spational heterogeneity of mtDNA polymorphism in natural populations of Drosophila mercatorum. Genetics, 116, 215-223.

ENGELS, w. R. 1981. Estimating genetic divergence and genetic variability with restriction endonucleases. Proc. Natl. Acad. Sci. USA, 78, 6329-6333.

Fos, M., Dominguez, M. A., LATORre, A. AND MoYA, A. 1990. Mitochondrial DNA evolution in experimental populations of Drosophila subobscura. Proc. Natl. Acad. Sci. USA, 87, 4198-4201.

HALE, L. R. AND SINGH, R. s. 1987. Mitochondrial DNA variation and genetic structure in populations of Drosophila melanogaster. Mol. Biol. Evol., 4, 622-637.

HARRISON, R. G. 1989. Animal mitochondrial DNA as a genetic marker in population and evolutionary biology. Trends in Ecology and Evolution, 4, 6-11.

KRIMBAS, C. B. AND LOUKAS, M. 1980. The inversion polymorphism of Drosophila suboscura. Evol. Biol., 12 , 163-234.

LAKOVAARA, S. AND SAURA, A. 1971. Genic variation in marginal populations of Drosophila subobscura. Hereditas, 69 , 77-82.

LAKOVAARA, S. AND SAURA, A. 1973. Genic variation in central and marginal populations of Drosophila subobscura. Hereditas, 75, 33-46.

LATORRE, A., MOYA, A. AND AYALA, F. J. 1986. Evolution of mitochondrial DNA in Drosophila subobscura. Proc. Natl. Acad. Sci. USA , 83, 8649-8653.

LATORRE, A., BARRIO, E., MOYA, A. AND AYAlA, F. J. 1988. Mitochondrial DNA evolution in the Drosophila obscura group. Mol. Biol. Evol., 5, 717-728.
LYNCH, M. AND CREASE, T. J. 1990. The analysis of population survey data on DNA sequence variation. Mol. Biol. Evol., 7, 377-394.

MARINKOVIC, D., AYALA, F. J. AND ANDJELKovic, M. 1978. Genetic polymorphism and phylogeny of Drosophila subobscura. Evolution, 32, 164-173.

NEI, M. 1973. Analysis of gene diversity in subdivided populations. Proc. Natl. Acad. Sci. USA, 70, 3321-3323.

NEI, M. 1987. Molecular Evolutionary Genetics. Columbia University Press, New York.

NIGRO, L. 1988. Natural populations of Drosophila simulans show great uniformity of the mitochondrial DNA restriction map. Genetica, 77, 133-137.

PINSKER, W., LANKINEN, P. AND SPERLICH, D. 1978. Allozyme and inversion polymorphism in a central European population of Drosophila subobscura. Genetica, 48, 207-214.

PREVOSTI, A., DE FRUTOS, R., ALONSO, G., LATORRE, A., MONCLUS, M. AND MARTINEZ, M. J. 1984. Genetic differentiation between natural populations of Drosophila subobscura in the western mediterranean area with respect to chromosomal variation. Genet. Sel. Evol., 16, 143-156.

PREVOSTI, A., RIBO, G., SERRA, L., AGUADE, M., BALAÑA, J., MONCLUS, M. AND MESTRES, F. 1988. Colonization of America by Drosophila subobscura: experiment in natural populations that supports the adaptive role of chromosomal-inversion polymorphism. Proc. Natl. Acad. Sci. USA, 85, 5597-5600.

RAND, D. M. AND HARRISON, R. G. 1989. Molecular population genetics of mtDNA size variation in crickets. Genetics, 121, 551-569.

SAURA, A., LAKOVAARA, S., LOKKI, J. AND LANKINEN, P. 1973. Genic variation in central and marginal populations of Drosophila subobscura. Hereditas, 75, 33-46.

SINGH, R. S. AND RHOMBERG, L. R. 1987. A comprehensive study of genic variation in natural populations of Drosophila melanogaster. I. Estimates of gene flow from rare alleles. Genetics, 115, 313-322.

SLATKIN, M. 1989. Population structure and evolutionary progress. Genome, 31, 196-202.

SOLIGNAC, M., MONNEROT, M. AND MOUNOLOU, J. C. 1986. Mitochondrial DNA evolution in the melanogaster species subgroup of Drosophila. J. Mol. Evol., 23, 31-40.

TAKAHATA, N. AND PALUMBI, s. 1985. Extranuclear differentation and gene flow in the finite island model. Genetics, 109, 441-457.

WEIR, B. S. AND COCKERHAM, C. C. 1984. Estimating F-statistics for the analysis of population structure. Evolution, 38, $1358-1370$.

ZOUROS, E., KRIMBAS, C. B., TSAKAS, S. AND LOUKAS, M. 1974. Genic versus chromosomal variation in natural populations of Drosophila subobscura. Genetics, 78, 1223-1244. 